\title{
Outcomes of patients with rodenticide poisoning at a far east poison center
}

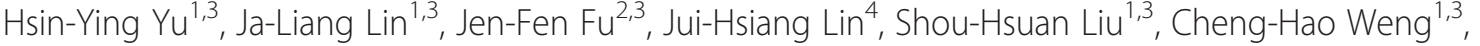 \\ Wen-Hung Huang ${ }^{1,3}$, Kuan-Hsing Chen ${ }^{1,3}$, Ching-Wei Hsu ${ }^{1,3}$ and Tzung-Hai Yen ${ }^{1,3^{*}}$
}

\begin{abstract}
Background: Rodenticide poisoning remains a major public health problem in Asian countries. Nevertheless, very few data are available in world literature regarding the outcomes of these patients. Therefore, the purpose of this study was to investigate the clinical outcomes of rodenticide poisonings in our hospital and to compare these data with published reports from other international poison centers.

Findings: We retrospectively examined the records of 20 patients with rodenticide poisoning (8 brodifacoum, 12 bromadiolone) who were referred to Chang Gung Memorial Hospital between 2000 and 2011. It was found that most of the rodenticide patients were middle-aged adults. Both genders were equally affected and many patients had a past history of major depressive disorder or schizophrenia. Nevertheless, patients with bromadiolone were referred significantly sooner than patients with brodifacoum poisoning $(0.1 \pm 0.1$ versus $5.5 \pm 10.5, P<0.001)$. Furthermore, it was found that patients with brodifacoum suffered higher incidences of ecchymosis (50.0\% versus $0 \%$, $\mathrm{P}=0.006)$ and hematuria ( $50.0 \%$ versus $0 \%, \mathrm{P}=0.006)$ than patients with bromadiolone poisoning. Laboratory analysis also demonstrated a poorer hemostatic profile of patients with brodifacoum [prothrombin time (PT), international normalized ratio (INR), $4.3 \pm 4.8$ versus $1.0 \pm 0.1, \mathrm{P}=0.032$; PT prolongation, $50.0 \%$ versus $0 \%, \mathrm{P}=0.006$; activated partial thromboplastin time (aPTT) prolongation, $50.0 \%$ versus $0 \%, \mathrm{P}=0.006$ ] than patients with bromadiolone poisoning. At the end of analysis, no patient died of the poisoning.
\end{abstract}

Conclusion: The favorable outcome (zero mortality rate) is comparable to the published reports from other international poison centers. Further studies are warranted.

Keywords: Brodifacoum; Bromadiolone; Rodenticide; Superwarfarin; Poisoning; Vitamin K1

\section{Introduction}

Superwarfarin rodenticide consists of two classes of compounds, the 4-hydroxycoumarins and the indandiones (Gunja et al. 2011). These compounds have replaced warfarin as an anticoagulant rodenticide. Given that the 4-hydroxycoumarin derivatives brodifacoum and bromadiolone are now the most frequently used rodenticides in Taiwan, they also account for the majority of rodenticide poisonings reported to our poison center.

Both brodifacoum and bromadiolone act by the same mechanism as warfarin but are 100 times more potent and have much longer serum and tissue half-lives (Park

\footnotetext{
* Correspondence: m19570@adm.cgmh.org.tw

'Department of Nephrology and Division of Clinical Toxicology, Chang Gung Memorial Hospital, 199 Tung Hwa North Road, Taipei 105, Taiwan

${ }^{3}$ College of Medicine, Chang Gung University, Taoyuan, Taiwan

Full list of author information is available at the end of the article
}

and Leck 1982). Coagulation factors II, VII, IX, X, and other vitamin $\mathrm{K}$-dependent proteins require gammacarboxylation of glutamic acid residues to be biologically active. In the carboxylation reaction, the cofactor vitamin $\mathrm{K}$ is converted to an inactive vitamin $\mathrm{K}$-2,3-epoxide. Active vitamin $\mathrm{K}$ is regenerated by epoxide reductase enzymes, which are blocked by warfarin and its analogs (Furie et al. 1999). The limited availability of active vitamin K produces a bleeding diathesis or complication.

The increased efficacy of superwarfarins as rodenticides results from their high lipid solubility, affinity for hepatic tissue and slow elimination from the body. The treatment of poisoned patients includes gastric lavage, followed by infusion of active charcoal, vitamin K1 therapy, and FFP transfusion in the case of bleeding (Caravati et al. 2007).

Rodenticide poisoning remains a major public health problem in Asian countries. Nevertheless, very few data 
are available in literature regarding the outcomes of these patients. Therefore, the purpose of this study was to investigate the clinical outcomes of these poisonings in our hospital and to compare these data with published reports from other international poison centers.

\section{Materials and methods Ethics}

This retrospective observational study complied with the guidelines of the Declaration of Helsinki and was approved by the Medical Ethics Committee of Chang Gung Memorial Hospital, a tertiary referral center located in the northern part of Taiwan. All primary data were collected according to the Strengthening the Reporting of Observational Studies in Epidemiology guidelines.

\section{Patients}

We examined the records of 20 patients with rodenticide poisoning who were examined at Chang Gung Memorial Hospital between 2000 and 2011. Demographic, clinical and laboratory data were collected, and the mortality rate was analyzed. Diagnosis of rodenticide intoxication was based on exposure history, and confirmed by clinical manifestations as well as physical and laboratory examination.

\section{Inclusion and exclusion criteria}

All patients who were diagnosed with rodenticide poisoning at Chang Gung Memorial Hospital between 2000 and 2011 were eligible for inclusion in this study. The type of rodenticide was verified by container or packaging information. Patients were excluded if the type of toxin swallowed was unknown even if there was a clinical suspicion of rodenticide intoxication. Finally, patients with co-ingestants or physical injury were also excluded from this analysis.

\section{Detoxification protocol}

The protocols used to treat patients included gastric lavage (in case of within 4 hours of exposure), followed by infusion of $1 \mathrm{~g} / \mathrm{kg}$ activated charcoal and $250 \mathrm{~mL}$ magnesium citrate via nasogastric tube. Magnesium citrate was used to prevent constipation after charcoal administration. At our hospital, the treatment of rodenticide poisoning was to administer vitamin $\mathrm{K} 1$ via an intramuscular route because the oral form of vitamin K1 was unavailable. Intravenous vitamin $\mathrm{K} 1$ infusion was avoided if possible due to the risk of anaphylaxis with this route of administration. Acute doses of prophylactic vitamin $\mathrm{K}$ were also given at emergency department to patients with a known ingestion of rodenticide who was asymptomatic, but the antidote was discontinued as soon as confirmation of no coagulopathy or bleeding. Finally, a transfusion of FFP was indicated for patients with active bleeding.

\section{Definitions of clinical events}

An ecchymosis was defined as a subcutaneous purpura of larger than $1 \mathrm{~cm}$. A subconjunctival hemorrhage was defined as a bleeding underneath the conjunctiva. Hypotension was defined as a systolic blood pressure of less than $90 \mathrm{mmHg}$ or diastolic blood pressure of less than $60 \mathrm{mmHg}$. Melena was defined as the discharge of black, tarry, bloody stools, usually resulting from a hemorrhage in the alimentary tract. Hematuria was defined as presence of blood in the urine. Prolongation of the PT and aPTT were based on an INR value $>1.5$ (Stanworth et al. 2011), or aPTT value of $>1.5$ times (Eby 1997) the laboratory mean control.

\section{Statistical analysis}

Continuous variables are expressed as means and standard deviations and categorical variables as numbers with percentages in brackets. All data were tested for normality of distribution and equality of standard deviations before analysis. For comparisons between patient groups, we used Student's $t$ test for quantitative variables and Chi-square or Fisher's exact tests for categorical variables. We considered results that rejected the null hypothesis with 95\% confidence to be significant. All analyses were performed with IBM SPSS Statistics Version 20.

\section{Results}

Most of the rodenticide patients were middle-aged adults (Table 1). Both genders were equally affected and many patients had a past history of major depressive disorder or schizophrenia. Furthermore, it was found that patients with bromadiolone were referred significantly sooner than patients with brodifacoum poisoning $(0.1 \pm 0.1$ versus $5.5 \pm 10.5$ hours, $\mathrm{P}<0.001$ )

Reported bleeding events included ecchymosis, subconjunctival hemorrhage, melena, and hematuria (Table 2). Some patients also complained of acute gastrointestinal symptoms, for example nausea, vomiting, abdominal distension, abdominal pain, etc. After analysis, it was revealed that patients with brodifacoum suffered higher incidences of bleeding complications, such as ecchymosis (50.0\% versus $0 \%, \mathrm{P}=0.006)$ and hematuria (50.0\% versus $0 \%, \mathrm{P}=0.006)$, than patients with bromadiolone poisoning (Table 2). Furthermore, laboratory analysis also demonstrated poorer hemostatic profiles for patients with brodifacoum (PT, INR, $4.3 \pm 4.8$ versus $1.0 \pm 0.1, \mathrm{P}=0.032$; $\mathrm{PT}$ prolongation, $50.0 \%$ versus $0 \%, \mathrm{P}=0.006$; aPTT prolongation, $50.0 \%$ versus $0 \%, \mathrm{P}=0.006)$ than patients with bromadiolone poisoning (Table 3).

As shown in Table 4, there were no significant differences in treatment modalities between these two groups. Finally, none of the patients died of the poisoning. 
Table 1 Baseline characteristics of patients with brodifacoum and bromadiolone rodenticide poisoning $(\mathrm{N}=20)$

\begin{tabular}{|c|c|c|c|}
\hline Variable & Bromadiolone $(\mathrm{N}=12)$ & Brodifacoum $(\mathrm{N}=8)$ & $P$ value \\
\hline Age, year & $37.3 \pm 25.7$ & $32.3 \pm 17.7$ & 0.639 \\
\hline Female, n (\%) & $6(50.0)$ & $5(62.5)$ & 0.582 \\
\hline Intentional, n (\%) & $9(75)$ & $7(87.5)$ & 0.494 \\
\hline Diabetes mellitus, n (\%) & $2(16.7)$ & $0(0)$ & 0.224 \\
\hline Hypertension, n (\%) & $3(25.0)$ & $0(0)$ & 0.125 \\
\hline Major depressive disorder and schizophrenia, n (\%) & $8(66.7)$ & $7(87.5)$ & 0.292 \\
\hline Alcohol consumption, n (\%) & $6(50.0)$ & $1(12.5)$ & 0.085 \\
\hline Smoking habit, n (\%) & $5(41.7)$ & $3(37.5)$ & 0.852 \\
\hline Betel nut chewing, $\mathrm{n}(\%)$ & $4(33.3)$ & $0(0)$ & 0.068 \\
\hline Therapeutic use of warfarin or antiplatelet drugs & $0(0)$ & $0(0)$ & 1.000 \\
\hline Time elapsed between poisoning and hospital arrival, hour & $0.1 \pm 0.1$ & $5.5 \pm 10.5$ & $<0.001^{* * *}$ \\
\hline
\end{tabular}

Note: ${ }^{* * *} \mathrm{P}<0.001$.

\section{Discussion}

There was no mortality in this study. The favorable outcome, shown in Table 4, is comparable to that of published reports from other international poison centers (Table 5), whose the mortality rate was also $0 \%$.

Nonetheless, there are few original studies reporting outcomes of bromadione poisoning in the literature. In 1998, Chua and Friedenberg (1998) reported 11 cases of superwarfarin poisoning from northern Wisconsin, USA. All 7 children had accidentally ingested superwarfarin, 2 adults had Munchausen syndrome, and 1 teenager and 1 adult had attempted suicide using superwarfarin. Nine of the 11 cases had taken brodifacoum. None of the patients died. In another study (Ingels et al. 2002), Ingels et al. prospectively examined 595 children younger than 6 years of age who reported to the California Poison Control System with acute unintentional superwarfarin ingestions. None of the patients had clinically important coagulopathy. Two patients had an INR of 1.5 or greater (1.5 and 1.8) without symptoms. Single nosebleeds were reported in another 2 patients with normal 48-hour INRs. Another child had a small amount of blood crusted in the nose with no other symptoms and no laboratory work available. One child with a normal 48-hour INR had blood-streaked stools that were thought to be caused by an anal fissure. However, the proportion of patients taking brodifacoum was not described. In another study (Shepherd et al. 2002), the American Association of Poison Control Centers (AAPCC) data from 1993 to 1996 were retrospectively reviewed for acute, unintentional brodifacoum exposures in children aged 6 years and younger. The analysis found 10,762 cases that involved single, acute, unintentional ingestions of brodifacoum. In this cohort, there were no deaths or major effects

Table 2 Clinical manifestations of patients with brodifacoum and bromadiolone rodenticide poisoning $(\mathrm{N}=20)$

\begin{tabular}{llll}
\hline Variable & Bromadiolone $(\mathbf{N}=\mathbf{1 2})$ & Brodifacoum $(\mathbf{N}=\mathbf{8})$ & P value \\
\hline Body temperature, ${ }^{\circ} \mathrm{C}$ & $36.1 \pm 0.5$ & $36.5 \pm 1.1$ & 0.331 \\
Pulse rate, per minute & $87.9 \pm 21.4$ & $98.4 \pm 24.1$ & 0.333 \\
Respiratory rate, per minute & $19.1 \pm 2.1$ & $21.0 \pm 2.4$ & 0.098 \\
Systolic pressure, $\mathrm{mmHg}$ & $148.4 \pm 39.7$ & $114.6 \pm 24.2$ & $0.049^{*}$ \\
Diastolic pressure, $\mathrm{mmHg}$ & $80.3 \pm 16.8$ & $70.4 \pm 17.8$ & 0.233 \\
Ecchymosis, $\mathrm{n}(\%)$ & $0(0)$ & $4(50.0)$ & $0.006^{* *}$ \\
Subconjunctival hemorrhage, $\mathrm{n}(\%)$ & $0(0)$ & $2(25.0)$ & 0.068 \\
Hypotension, $\mathrm{n}(\%)$ & $0(0)$ & $2(25.0)$ & 0.068 \\
Nausea, $\mathrm{n}(\%)$ & $1(8.3)$ & $1(12.5)$ & 0.761 \\
Vomiting, $\mathrm{n}(\%)$ & $2(16.7)$ & $2(25.0)$ & 0.648 \\
Abdominal distension, $\mathrm{n}(\%)$ & $0(0)$ & $1(12.5)$ & 0.209 \\
Abdominal pain, $\mathrm{n}(\%)$ & $4(33.3)$ & $2(25)$ & 0.690 \\
Melena, $\mathrm{n}(\%)$ & $1(8.3)$ & $3(37.5)$ & 0.110 \\
Hematuria, $\mathrm{n}(\%)$ & $0(0)$ & $4(50.0)$ & $0.006^{* *}$ \\
\hline
\end{tabular}

Note: ${ }^{*} \mathrm{P}<0.05,{ }^{*} \mathrm{P}<0.01$. 
Table 3 Laboratory findings of patients with brodifacoum and bromadiolone rodenticide poisoning $(\mathrm{N}=20)$

\begin{tabular}{|c|c|c|c|}
\hline Variable & Bromadiolone $(\mathrm{N}=12)$ & Brodifacoum $(\mathrm{N}=8)$ & $P$ value \\
\hline \multicolumn{4}{|l|}{ Blood test } \\
\hline Red blood cell, $\times 10^{6} / / \mathrm{uL}$ & $4.5 \pm 0.6$ & $4.2 \pm 1.3$ & 0.422 \\
\hline Hemoglobin & $13.1 \pm 2.2, \mathrm{~g} / \mathrm{dL}$ & $12.0 \pm 3.6$ & 0.382 \\
\hline Platelet, 1000/uL & $233.8 \pm 62.4$ & $257.1 \pm 140.5$ & 0.616 \\
\hline White blood cell, 1000/uL & $6.9 \pm 1.7$ & $11.3 \pm 9.7$ & 0.143 \\
\hline Neutrophils, \% & $61.7 \pm 12.7$ & $59.6 \pm 21.2$ & 0.786 \\
\hline Aspartate aminotransferase, $\mathrm{U} / \mathrm{L}$ & $31.4 \pm 17.1$ & $28.5 \pm 5.9$ & 0.702 \\
\hline Alanine aminotransferase, $U / L$ & $28.6 \pm 23.2$ & $28.0 \pm 29.1$ & 0.962 \\
\hline Albumin, $\mathrm{g} / \mathrm{dL}$ & $4.0 \pm 0.4$ & $4.3 \pm 0.4$ & 0.343 \\
\hline Total bilirubin, mg/dL & $0.7 \pm 0.1$ & $0.6 \pm 0.1$ & 0.468 \\
\hline Blood urea nitrogen, mg/dL & $10.5 \pm 4.8$ & $13.1 \pm 6.7$ & 0.475 \\
\hline Creatinine, mg/dL & $0.7 \pm 0.3$ & $0.8 \pm 0.2$ & 0.827 \\
\hline Calcium, mg/dL & $9.1 \pm 0.8$ & $8.9 \pm 0.6$ & 0.730 \\
\hline Phosphate, mg/dL & $4.0 \pm 1.1$ & $2.8 \pm 0.2$ & 0.416 \\
\hline Sodium, mEq/L & $142.9 \pm 2.5$ & $143.2 \pm 3.5$ & 0.861 \\
\hline Potassium, mEq/L & $4.0 \pm 0.3$ & $4.0 \pm 0.3$ & 1.000 \\
\hline Chloride, mEq/L & $110.5 \pm 7.8$ & $108.0 \pm 4.2$ & 0.728 \\
\hline Glucose, mg/L & $107.7 \pm 34.8$ & $110.0 \pm 7.1$ & 0.935 \\
\hline Cholesterol, mg/dL & $135.5 \pm 21.9$ & $210.0 \pm 21.0$ & 0.220 \\
\hline Triglyceride, mg/dL & $207.0 \pm 41.0$ & $502.0 \pm 50.2$ & 0.081 \\
\hline C-reactive protein $\mathrm{mg} / \mathrm{L}$ & $16.1 \pm 1.6$ & $7.1 \pm 11.4$ & 0.562 \\
\hline PT, INR & $1.0 \pm 0.1$ & $4.3 \pm 4.8$ & $0.032^{*}$ \\
\hline PT prolongation, n (\%) & $0(0)$ & $4(50)$ & $0.006^{* *}$ \\
\hline aPT, n (\%) & $0(0)$ & $4(50)$ & $0.006^{* *}$ \\
\hline \multicolumn{4}{|l|}{ Urine test } \\
\hline Blood, n (\%) & $0(0)$ & $5(62.5)$ & $0.004^{* *}$ \\
\hline Red blood cell, per HPF & $0 \pm 0$ & $217.6 \pm 264.3$ & 0.206 \\
\hline \multicolumn{4}{|l|}{ Stool test } \\
\hline Occult blood, n (\%) & $1(8.3)$ & $1(12.5)$ & 0.910 \\
\hline
\end{tabular}

Note: Activated partial thromboplastin time, HPF high power field, INR International normalized ratio, $P T$ Prothrombin time *P $<0.05$, **P $<0.01$.

reported. Although 67 patients reported evidence of coagulopathy, no major effects or deaths were reported. Minor and moderate effects were reported in 38 and 54 children, respectively. Approximately half of all the children received some form of gastrointestinal decontamination, which had no effect on the distribution of outcomes but which caused adverse effects in 42 patients. In another study (Wu et al. 2009), Wu et al. studied 9 Taiwanese cases of superwarfarin poisoning at the Changhua Christian Hospital, seven of which were brodifacoum intoxication. Of the 9 patients, hematuria occurred in eight. Laboratory tests showed extremely prolonged PT and

Table 4 Treatment outcomes of patients with brodifacoum and bromadiolone rodenticide poisoning $(\mathrm{N}=\mathbf{2 0})$

\begin{tabular}{llll}
\hline Variable & Bromadiolone $\mathbf{( N = 1 2 )}$ & Brodifacoum (N=8) & $\mathbf{P}$ \\
\hline Gastric lavage, $\mathrm{n}(\%)$ & $7(58.3)$ & $4(50)$ & 0.588 \\
Active charcoal and magnesium citrate, n (\%) & $6(50.0)$ & $2(25.0)$ & 0.303 \\
Vitamin K1, n (\%) & $10(83.3)$ & $6(75.0)$ & 0.450 \\
FFP, n (\%) & $0(0)$ & $3(37.5)$ & 0.059 \\
Mortality, n (\%) & $0(0)$ & $0(0)$ & 1.000 \\
\hline
\end{tabular}

Note: FFP Fresh frozen plasma. 


\begin{tabular}{|c|c|c|c|c|c|c|}
\hline Study & Year & Area & Sample size & Proportion of brodifacoum & Outcome & Mortality rate \\
\hline \multirow[t]{2}{*}{ Chua and Friedenberg (1998) } & 1998 & USA & 11 & Brodifacoum (9/11) & Ecchymosis (1/11) & 0 \\
\hline & & & & & Hematuria $(1 / 11)$ & \\
\hline Ingels et al. (2002) & 2002 & USA & 545 & Not reported & Not reported & 0 \\
\hline Shepherd et al. (2002) & 2002 & USA & 10762 & Brodifacoum (10762/10762) & Not reported & 0 \\
\hline \multirow[t]{2}{*}{ Wu et al. (2009) } & 2009 & Taiwan & 9 & Brodifacoum (7/9) & Ecchymosis (5/9) & 0 \\
\hline & & & & & Hematuria (8/9) & \\
\hline \multirow[t]{2}{*}{ Hong et al. (2010) } & 2010 & Korea & 10 & Brodifacoum (5/10) & Ecchymosis (4/10) & 0 \\
\hline & & & & & Hematuria $(4 / 10)$ & \\
\hline \multirow[t]{2}{*}{ Current study } & 2011 & Taiwan & 20 & Brodifacoum (8/20) & Ecchymosis (4/20) & 0 \\
\hline & & & & & Hematuria (4/20) & \\
\hline
\end{tabular}

aPTT, which could be corrected to normal by mixing 1:1 with normal pooled plasma; they also had very low functional levels of factor II, VII, IX, X, and proteins C and S, but normal functional levels of factors V, VIII, fibrinogen, and anti-thrombin III. Large doses of vitamin K1 were needed for 3 months or more to treat and correct the coagulopathy among the patients. The majority of the patients presented with gross hematuria, and thus required prolonged use of large doses of vitamin K1 for the treatment of superwarfarin intoxication. Finally, Hong et al. (Hong et al. 2010) found 10 Korean patients diagnosed as or highly suspicious for superwarfarin intoxication at Gachon University Gil Hospital. Bleeding symptoms varied among the patients and patients uniformly showed prolonged PT and aPTT with decreased activity of vitamin $\mathrm{K}$ dependent coagulation factors. Positive serum brodifacoum test results in 4 of 5 requested patients contributed to confirmatory diagnosis. High dose vitamin K1 therapy promptly corrected the prolonged PT and aPTT, but hasty discontinuation caused repeated bleeding diathesis in 6 patients. Therefore, high dose and prolonged use of vitamin K1 therapy was necessary for effective detoxification.

In this study, it was found that patients with brodifacoum suffered higher incidences of bleeding complications, such as ecchymosis $(\mathrm{P}=0.006)$ and hematuria $(\mathrm{P}=0.006)$, than patients with bromadiolone poisoning (Table 2). Previous laboratory studies also indicated that the acute lethal dose 50 (LD50) for these two rodenticides were quite different. For example, the acute LD50 of brodifacoum for various animals were rats 0.27 $0.30 \mathrm{mg} / \mathrm{kg}$ body weight (bw), mice $0.40 \mathrm{mg} / \mathrm{kg} \mathrm{bw}$, rabbits $0.30 \mathrm{mg} / \mathrm{kg} \mathrm{bw}$, guinea-pigs $0.28 \mathrm{mg} / \mathrm{kg}$ bw, cats $25 \mathrm{mg} / \mathrm{kg}$ bw and dogs 0.25-3.6 mg/kg bw (Brodifacoum Web 2013); on the other hand, the acute LD50 of bromadiolone for various animals were rats $1.125 \mathrm{mg} / \mathrm{kg} \mathrm{bw}$, mice $1.75 \mathrm{mg} / \mathrm{kg}$ bw, rabbits $1 \mathrm{mg} / \mathrm{kg}$ bw, dogs $>10 \mathrm{mg} / \mathrm{kg}$ bw and cats $>25 \mathrm{mg} / \mathrm{kg}$ bw (Bromadiolone Web 2013).
Another consideration is the speedy of hospital referral. In this study, it was found that patients with bromadiolone were referred significantly sooner than patients with brodifacoum poisoning (Table 1). Therefore, it seems reasonable to consider that patients who present very soon after oral exposure and who receive aggressive gastric decontamination procedures would be less likely to develop clinical signs and symptoms of the exposure when compared to a group that have delayed presentation to the emergency department and delays in receiving gastric emptying treatments.

There were only 20 cases of rodenticide poisonings discovered over a period of 11 years (Table 1). In contrast to numerous cases of poisonings due to other toxins (Yang et al. 2012; Liu et al. 2012; Lin et al. 2012; Lin et al. 2011), the data indicate that rodenticide exposure in Taiwan is relatively uncommon. Similarly, Berny et al. (Berny et al. 2010) also found that the number of anticoagulant exposures reported to the Lyon Poison Control Center was very limited. This might be the result of the addition of bittering agents (Mason et al. 1985) into the formulations of rodenticides, which make them less tasty. Similarly, this might help explain why most of the rodenticide cases were also sufferers of major depressive disorders or schizophrenia (Table 1); because these patients often had distorted perception of reality.

In conclusion, the data is important because it is one of few original reports on Asian patients with rodenticide poisoning. Furthermore, the favorable outcome (zero mortality rate) is comparable to the published reports from other international poison centers. Nevertheless, the retrospective nature of the study, the small patient population, and the short follow-up duration are limitations that warrant further investigations to validate the conclusion drawn here.

\section{Competing interests}

The authors declare that they have no competing interests. 


\section{Authors' contributions}

HYY carried out the study and drafted the manuscript. JLL, FJF and JHL participated in the design of the study and performed the statistical analysis. THY conceived of the study, and participated in its design and coordination and helped to draft the manuscript. All authors read and approved the final manuscript.

\section{Acknowledgements}

THY was funded by research grants from the Chang Gung Memorial Hospital (CMRG3C0771) and National Science Council of Taiwan (NSC102-2314-B-182 044- and NSC101-2314-B-182A-102-MY2), respectively.

\section{Author details}

'Department of Nephrology and Division of Clinical Toxicology, Chang Gung Memorial Hospital, 199 Tung Hwa North Road, Taipei 105, Taiwan.

${ }^{2}$ Department of Medical Research, Chang Gung Memorial Hospital, Linkou, Taiwan. ${ }^{3}$ College of Medicine, Chang Gung University, Taoyuan, Taiwan.

${ }^{4}$ Department of Nephrology, Taoyuan General Hospital, Taoyuan, Taiwan.

Received: 17 July 2013 Accepted: 1 October 2013

Published: 3 October 2013

\section{References}

(2013a) Brodifacoum Web address, http://en.wikipedia.org/wiki/Brodifacoum (2013b) Bromadiolone. Web address, http://en.wikipedia.org/wiki/Bromadiolone Berny P, Velardo J, Pulce C, D'Amico A, Kammerer M, Lasseur R (2010) Prevalence of anticoagulant rodenticide poisoning in humans and animals in France and substances involved. Clin Toxicol (Phila) 48(9):935-941, 10.3109/15563650.2010.533678

Caravati EM, Erdman AR, Scharman EJ, Woolf AD, Chyka PA, Cobaugh DJ, Wax PM, Manoguerra AS, Christianson G, Nelson LS, Olson KR, Booze LL, Troutman WG (2007) Long-acting anticoagulant rodenticide poisoning: an evidence-based consensus guideline for out-of-hospital management. Clin Toxicol (Phila) 45(1):1-22

Chua JD, Friedenberg WR (1998) Superwarfarin poisoning. Arch Intern Med 158(17):1929-1932

Eby C (1997) Standardization of APTT reagents for heparin therapy monitoring: urgent or fading priority? Clin Chem 43(7):1105-1107

Furie B, Bouchard BA, Furie BC (1999) Vitamin K-dependent biosynthesis of gamma-carboxyglutamic acid. Blood 93(6):1798-1808

Gunja N, Coggins A, Bidny S (2011) Management of intentional superwarfarin poisoning with long-term vitamin $\mathrm{K}$ and brodifacoum levels. Clin Toxicol (Phila) 49(5):385-390, 10.3109/15563650.2011.587126

Hong J, Yhim HY, Bang SM, Bae SH, Yuh YJ, Yoon SS, Yoon HJ, Kim ST, Chi HS (2010) Korean patients with superwarfarin intoxication and their outcome. J Korean Med Sci 25(12):1754-1758, 10.3346/jkms.2010.25.12.1754

Ingels M, Lai C, Tai W, Manning BH, Rangan C, Williams SR, Manoguerra AS, Albertson T, Clark RF (2002) A prospective study of acute, unintentional, pediatric superwarfarin ingestions managed without decontamination. Ann Emerg Med 40(1):73-78

Lin JL, Lin-Tan DT, Chen KH, Huang WH, Hsu CW, Hsu HH, Yen TH (2011) Improved survival in severe paraquat poisoning with repeated pulse therapy of cyclophosphamide and steroids. Intensive Care Med 37(6):1006-1013, doi:10.1007/s00134-010-2127-7

Lin C, Yen TH, Juang YY, Leong WC, Hung HM, Ku CH, Lin JL, Lee SH (2012) Comorbid psychiatric diagnoses in suicide attempt by charcoal burning: a 10-year study in a general hospital in Taiwan. Gen Hosp Psychiatry 34(5):552-556, 10.1016/j.genhosppsych.2012.03.015

Liu SH, Lin JL, Weng CH, Yang HY, Hsu CW, Chen KH, Huang WH, Yen TH (2012) Heart rate-corrected QT interval helps predict mortality after intentional organophosphate poisoning. PLoS One 7(5):e36576, doi:10.1371/journal. pone.0036576 PONE-D-11-23859

Mason JR, Reidinger RF Jr, Stewart CN (1985) Profiling, mimicking and masking the flavor of a selected rodenticide. Physiol Behav 35(1):127-134

Park BK, Leck JB (1982) A comparison of vitamin K antagonism by warfarin, difenacoum and brodifacoum in the rabbit. Biochem Pharmacol 31(22):3635-3639

Shepherd G, Klein-Schwartz W, Anderson BD (2002) Acute, unintentional pediatric brodifacoum ingestions. Pediatr Emerg Care 18(3):174-178

Stanworth SJ, Walsh TS, Prescott RJ, Lee RJ, Watson DM, Wyncoll D, Intensive Care Study of Coagulopathy i (2011) A national study of plasma use in critical care: clinical indications, dose and effect on prothrombin time. Crit Care 15(2):R108, doi:10.1186/cc10129

Wu YF, Chang CS, Chung CY, Lin HY, Wang CC, Shen MC (2009) Superwarfarin intoxication: hematuria is a major clinical manifestation. Int J Hematol 90(2):170-173, doi:10.1007/s12185-009-0374-6

Yang CJ, Lin JL, Lin-Tan DT, Weng CH, Hsu CW, Lee SY, Lee SH, Chang CM, Lin WR, Yen TH (2012) Spectrum of toxic hepatitis following intentional paraquat ingestion: analysis of 187 cases. Liver Int 32(9):1400-1406, doi:10.1111/j.14783231.2012.02829.x

doi:10.1186/2193-1801-2-505

Cite this article as: Yu et al:: Outcomes of patients with rodenticide poisoning at a far east poison center. SpringerPlus 2013 2:505.

\section{Submit your manuscript to a SpringerOpen ${ }^{\odot}$ journal and benefit from:}

- Convenient online submission

- Rigorous peer review

- Immediate publication on acceptance

- Open access: articles freely available online

- High visibility within the field

- Retaining the copyright to your article

Submit your next manuscript at $>$ springeropen.com 